\title{
CRISIS PHENOMENA AT MECHANICAL ENGINEERING ENTERPRISES: CAUSES, PROBLEMS OF ANTI-CRISIS MANAGEMENT, WAYS TO OVERCOME
}

\author{
Shvets Yu. O., Sisoeva P. K. \\ Zaporizhzhia National University \\ Ukraine, 69600, Zaporizhzhia, Zhukovsky str., 66. \\ yuliashvets@ukr.net, daria19synioka@gmail.com \\ ORCID ID 0000-0002-0294-1889, ORCID ID 0000-0001-5020-5213
}

\section{Key words:}

economic crisis, crisis, crisis phenomena, machine-building enterprise, anti-crisis management, monitoring, strategy, anti-crisis potential.
Today's situation in Ukraine has a negative impact on the engineering industry. Political and economic instability, the war in the east and the global financial crisis have led to a systemic crisis in the national economy. The set of negative factors that prompted the crisis processes require the creation and application of a mechanism of crisis management, based on a comprehensive analysis of the dynamics and factors of their occurrence. The crisis as a phenomenon in the machine-building enterprise is caused by poor management and strategy of the organization, ineffective efforts to maintain a competitive position in the market. The conceptual apparatus on the research topic is considered in the article. A socioeconomic analysis of the state of the machine-building industry has been carried out. External and internal factors of crisis phenomena at the enterprise are considered. The types of crises that occur in the engineering industry have been identified. The relationship between anti-crisis crisis management as an anti-crisis potential for overcoming crises is described. Crisis phenomena were identified on the example of an individual enterprise. Features and conditions that determine the effectiveness of the mechanism of crisis management in machine-building enterprises were considered. It was found that the anti-crisis management of the enterprise is also influenced by additional factors that are formed on certain grounds: scale, condition, causes. It is established that the main anti-crisis potential includes the following components: production, financial, resource, organizational and managerial, information, labor. The main ways of counteracting crisis phenomena at the enterprise of PAT AK «Bohdan Motors» are considered. The main causes of the crisis were identified at the analyzed enterprise and the problems of anti-crisis management were identified. It was found that effective incentives for crisis management will be: insurance of financial risks to cover the equity deficit, taking measures to achieve receivables, reducing financial transactions in the most risky areas of activity, the introduction of crisis rehabilitation and restructuring.

\section{КРИЗОВІ ЯВИЩА НА ПІДПРИСМСТВАХ МАШИНОБУДУВАННЯ: ПРИЧИНИ ВИНИКНЕННЯ, ПРОБЛЕМИ АНТИКРИЗОВОГО УПРАВЛІННЯ, ШЛЯХИ ПОДОЛАННЯ}

\author{
Швець Ю. О, Сисосва П. О. \\ Запорізький національний університет \\ Україна, 69600, м. Запоріжжя, вул. Жуковського, 66
}

\begin{abstract}
Ключові слова:
економічна криза, криза, кризові явища, підприємство машинобудування, антикризове управління, моніторинг, стратегія, антикризовий потенціал.
\end{abstract}

Сьогоднішня ситуація в Україні негативно впливає на машинобудівну галузь. Політико-економічна нестабільність, війна на сході та світова фінансова криза призвели до системної кризи національного господарства. Сукупність негативних факторів, що підштовхнули до кризових процесів вимагають створення та застосування механізму антикризового управління, що базується на комплексному аналізі динаміки та факторів їх виникнення. Криза як явище на підприємстві машинобудування спричинено невдалим керуванням та стратегією організації, неефективними зусиллями для підтримання конкурентних позицій на ринку. У статті розглянуто понятійний апарат 3 теми дослідження. Здійснено соціально-економічний аналіз стану машинобудівної галузі. Розглянуто зовнішні та внутрішні фактори кризових явищ на підприємстві. 3'ясовані різновиди криз, що виникають в машинобудівній галузі. Охарактеризовано взаємозв'язок антикризового управління кризами в якості антикризового потенціалу для подолання криз. Ідентифікували кризові явища на прикладі окремого підприємства. Розглянули особливості та умови, що визначають ефективність функціонування механізму антикризового управління на підприємствах машинобудування. 3'ясовано, що на антикризове управління підприємства також впливають додаткові фактори, що сформовані за певними ознаками: за масштабом, за станом, за причинами. Встановлено, що до основного антикризового потенціалу входять такі складові: виробнича, 
фінансова, ресурсна, організаційно-управлінська, інформаційна, трудова. Розглянуто основні шляхи протидії кризовим явищам на підприємстві ПАТ АК «Богдан Моторс». На аналізованому підприємстві визначено основні причини кризи та виділено проблеми антикризового управління. 3'ясовано, що ефективними стимулами антикризового управління будуть: страхування фінансових ризиків покриття дефіциту власного капіталу, вживання заходів 3 досягнення дебіторської заборгованості, скорочення фінансових операцій на найбільш ризикованих напрямках діяльності, упровадження антикризових санацій та реструктуризації.

\section{Statement of the problem}

Depending on the impact of the crisis on machine-building enterprises, there is a need for crisis management to overcome the crisis. Also, the company needs to form the structure and content of the components of anti-crisis potential, take into account the peculiarities of transformation processes in accordance with the requirements of management during the crisis. Also at machine-building enterprises it is necessary to analyze the causes of crisis phenomena, to determine the effectiveness of crisis management and to form ways to overcome the crisis. In our opinion, the effectiveness of crisis management is the introduction of radical, preventive, stabilization mechanisms by which the company can work effectively.

\section{Analysis of recent studies and publications}

The topic of crisis management is quite relevant, so many domestic and foreign scientists have studied it. In the scientific works of Banera N.P. discusses the peculiarities of the formation of financial crises and the scientist believes that cost optimization, effective use of marketing system, strict personnel policy, improving the quality of information support, continuous prevention of anti-crisis measures will help to quickly overcome the crisis in the enterprise [1, p. 14]. On mind Vynokurova O. I. in overcoming the crisis at the enterprise it is necessary to form a unique anti-crisis business plan, which includes marketing, production and personnel measures [2, p. 54]. The scientist believes that for each company and its crisis situation you need to form their own unique anti-crisis actions. For example Huk O.V. believes that there is a functional and systemic group in crisis management. The functional group embodies changes in the activities of managers and staff of the enterprise, while the system group is solved only through the restructuring of the enterprise [4, p. 193]. Davydenko V.V. in most scientific works proves that to identify crisis trends need to apply a set of measures for preventive management, they can generate reliable information about the crisis in the enterprise through the analysis of external and internal factors [5, p. 279]. Pohrishchuk H.B. analyzes the crisis situation of machine-building enterprises in Ukraine and in his opinion the topic is currently insufficiently studied and needs refinement and deepening of the formation and application of anti-crisis actions on the example of individual enterprises [10, p. 463].

However, reviewing the scientific literature, we noted that there are a number of unresolved issues related to the problems of applied tools of crisis management and its relationship with crisis phenomena, as well as assessing the effectiveness of the choice of existing measures that will stimulate the exit of enterprises engineering industry from the crisis.

\section{Objectives of the article}

The purpose of the article is to determine the causes of crisis phenomena, problems of crisis management and to develop ways to overcome the crisis on the example of the company PAT AK «Bohdan Motors».

\section{The main material of the research}

There are many interpretations of the concept of «crisis» in the scientific literature, but we will focus on one that is the most optimal. The crisis of the enterprise is a state that is limited, repeated in time, it is characterized by persistent strong fluctuations outside the corridor of acceptable values [7, p. 37]. Crisis phenomena usually occur as a result of a sharp loss of the ability of any enterprise to adapt to the pace and impact of changes in the environment at different levels due to the violation of the relationships between the development cycles of individual components of the enterprise system. Most scientists emphasize that the crisis in the engineering industry has both positive and negative consequences.

The internal factors influencing the crisis on the company include the wrong choice of development strategy, ineffective tactical steps associated with various management decisions. External factors include: the state of the economy in the country and the world, the instability of tax and economic legislation, seasonal fluctuations, increased competition, political and economic instability, increasing market monopoly. Equally important is the level of inflation and instability of the financial and foreign exchange markets, which reduce the purchasing power of the population and lead to crisis processes of enterprises.

In the scientific literature there are many types of crises of the enterprise, mostly they are classified: by time of impact (short-term, medium-term, long-term); by origin (objective, subjective, natural, artificial, cyclical, regular, random); by consequences (recovery, destruction, sharp fall, soft exit, exacerbation, new, renewal); by stages of development (potential, explicit, destructive, latent); by intensity of impact (slow, reactive, intense) [12, p. 19]. Also classify crises of the enterprise: by stages of the life cycle of the enterprise; by area of origin; by factors of destabilizing influence; by the degree of use of the potential of the enterprise; if possible, forecasting the enterprise; for special management functions; if possible to overcome; by changes in the crisis over time [11, p. 130].

Considering scientific works Cherep A.V. it is possible to pay attention that the author emphasizes preparation and forecasting of crisis at the enterprise during calculations of financial and economic indicators, it is necessary to carry out the preventive anti-crisis program. This program will be aimed at increasing flexibility within the enterprise, development of preparatory plans to prevent crisis situations and preventive measures to implement the 
plans. Such measures include: strategic controlling, formation of insurance funds, strategic reserve of funds, technical means [13, p. 178].

In relation to various components of the crisis phenomenon at the enterprise anti-crisis management is carried out. On mind Skibitskyi O. M., anti-crisis management is an organized process aimed at identifying, preventing and eliminating crisis phenomena by implementing appropriate functions at the strategic and tactical levels in order to ensure the functioning and development of the enterprise [12, p. 21].
A feature of crisis management is the integration of the system of diagnosis, prevention, crisis management, restructuring strategy, which leads to the use of effective non-standard methods in personnel management.

On the example of the machine-building enterprise of PAT AK «Bohdan Motors» we calculated the indicators influencing the state of crisis phenomena at the enterprise, among them: liquidity, business activity, financial stability, profitability (tabl. 1).

Table 1 - Group of indicators PAT AK «Bohdan Motors» in 2015-2019 year

\begin{tabular}{|c|c|c|c|c|c|}
\hline Group of indicators & $\mathbf{2 0 1 5}$ & $\mathbf{2 0 1 6}$ & $\mathbf{2 0 1 7}$ & $\mathbf{2 0 1 8}$ & $\mathbf{2 0 1 9}$ \\
\hline Liquidity & 0,07 & 0,17 & 0,18 & 0,003 & 0,28 \\
\hline Business activity & 2,25 & 2,5 & 2,66 & 1,7 & 4,24 \\
\hline Financial stability & 0,98 & 0,41 & 0,68 & 0,38 & 0,280 \\
\hline Profitability & 0,05 & 0,9 & $-0,07$ & $-0,35$ & $-0,4$ \\
\hline
\end{tabular}

Source: compiled by the author based on calculations [9]

So, on the basis of these indicators, we diagnosed the crisis of the enterprise PAT AK «Bohdan Motors» 3a the last 5 years, the data will allow us to understand from what period the company's performance began to deteriorate. To calculate, we used the method of harmonic scales Brauna R., which is a method of adaptive forecasting [8, p. 532]. In this method, you can determine the current trend, not the current average. Indicators of «business activity» show a declining trend every year and this means that it is necessary to optimize the quality of costs at the enterprise, repay receivables, ensure high growth rates of production and sales of engineering products. As for the indicators of «financial stability», they are also ambiguous and indicate instability. In order to improve these indicators, the company needs to increase retained earnings, update fixed assets through loans (leasing), control the dynamics of short-term liabilities, increase the efficiency of current production. Indicators of «profitability» have negative indicators and this means that the company needs to change markets and adjust pricing and product quality to compete with other manufacturers.

First you need to form a phase, so to $\mathrm{k}$ includes from 3 to 5 levels of the initial series of dynamics. The first phase is equal $y_{1}, y_{2}, \ldots, y_{k}$, second phase $y_{2}, y_{3}, \ldots, y_{k+1}, \quad$ third phase $y_{n \cdot k+1}, y_{n \cdot k+2}, \ldots, y_{n}$. Therefore, we can say that the number of phases will be equal $\mathrm{K}=\mathrm{n}-\mathrm{k}+1 \quad[6$, p. 49].

Using the method of least squares we can find linear regression equations, ie the equation of flowing trends $[8$, p. 534]:

$\left.\stackrel{\wedge}{y_{i}}(\mathrm{t})=b_{0 i}+b_{1 i t}{ }^{(i=1} 1, K^{;}{ }^{\mathrm{t}}=i, i+k-1\right)$,

where $b_{0 i}, b_{1 i t}$ are estimation coefficients that connect exponential averages according to the coefficients of the trend equation; $\mathrm{t}$ - derived from time; $y_{1}$ - initial values of the time series; $\wedge$ - the value of the exponential mean; $k-1$ - local trend; $K$ - discrete time; $i$ - the number of the row value, starting with the numbering from the last value.

Based on the found trends, we calculate the average values of the current trend $i=1, n$.

Then you need to check the assumption that deviations from the current trend are random and constitute a stationary process. Therefore, we used the autocorrelation error function. The next step is to calculate the average increments [14, p. 12]:

$W_{t+1}={ }_{y}(t+1)-y(t)$

where $\mathrm{t}+1$ - reflects the process of development of the studied indicator over time, determine the projected value for the period, while minimizing the standard errors of

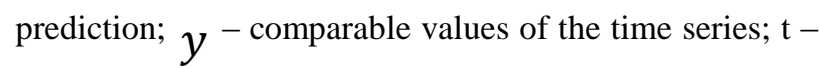
derived from time.

The formula helps us to find the average increase [8, p. 535]:

$\bar{W}=\sum_{t=1}^{n-1} C_{t+1} \cdot W_{t+1}$

It turns out that $C_{t+1}$ - harmonic coefficient, which can be calculated on the basis of harmonic weights, $t+1-$ reflects the process of development of the studied indicator over time, determine the projected value for the period provided that the rms of prediction errors are minimized.

To do this, we use the following relationship [8, p. 536]:

$$
\begin{gathered}
m_{t+1}=\sum_{i=1}^{t} \frac{1}{n-1}, \\
m_{t+1}=m_{t}+\frac{1}{n-t}(t=1, n-1),
\end{gathered}
$$


where $n-1$ - the number of levels of a series of dynamics, $m_{t+1}$ - period of oscillations. We determined the harmonic coefficient by the formula [14, p. 13]:

$$
C_{t+1}=\frac{m_{t+1}}{n-1} \text {. }
$$

The point forecast is found as the sum of the last value of a series of dynamics and average growth [14, p. 15]:

$$
\mathrm{y} \frac{\text { forecast }}{t+1}=\overline{y(t)}+\bar{W}
$$

where $t+1$ - forecast level of the series, $y$-comparable values of the time series. The confidence interval of the predicted value is found using the Chebysheva inequality for a random variable $W_{t+1}$ [8, p. 538]:

$\mathrm{P}\left\{\left|W_{t+1}-E(W)\right|>a \sigma_{w}\right\}<\frac{1}{a^{2}}$,

where a - given a positive integer; $t+1$ - forecast level of the series; $\sigma_{W}-\epsilon$ the standard deviation of a random variable whose estimate is [8, p. 539]:

$$
\sigma_{W}=\sqrt{\sum_{t=1}^{n-1} C_{t+1}\left(W_{t+1}-\bar{W}\right)^{2}}
$$

де $\mathrm{t}+1$ - forecast level of the series; ${ }^{\wedge}-$ the value of the exponential mean; $t=1$ - coefficient of the time trend equation. The confidence limits for the forecast value of the indicator will be [8, p. 539]:

$$
\begin{aligned}
& { }_{n+\tau}^{\text {forecast }}-A(\tau)_{\sigma_{w}}^{\wedge} \leq y \leq y_{n+\tau}^{\text {forecast }}+ \\
& A(\tau)_{\sigma_{w}}
\end{aligned}
$$

In this formula $\tau$-forecasting horizon; ${ }^{\wedge}-$ the value of the exponential mean; magnitude $A(\tau)$ calculated by the formula [8, p. 540]:

$$
A(\tau)=a \sum_{t=1}^{\tau+1} C_{n-1+1},
$$

where a - smoothing parameters; $\tau$ - forecasting horizon; $t=1$ - coefficient of the time trend equation. Based on the mathematical apparatus, we were able to calculate the value of the integrated indicator of the effectiveness of the crisis management mechanism PAT AK «Bohdan Motors», the data are formed in table. 2 [9, p. 468].

Table 2 - Calculation of forecast values of the integrated indicator of the effectiveness of the crisis management mechanism PAT AK «Bohdan Motors»

\begin{tabular}{|l|c|c|c|c|c|c|c|c|}
\hline Years & $\begin{array}{c}\text { The value of the } \\
\text { integrated indicator }\end{array}$ & $\begin{array}{c}\text { Phases of the } \\
\text { current trend }\end{array}$ & $\boldsymbol{a}_{\mathbf{0}}$ & $\boldsymbol{a}_{\mathbf{1}}$ & $\overline{\boldsymbol{y}}$ & $\boldsymbol{W}_{\boldsymbol{t + 1}}$ & $\boldsymbol{m}_{\boldsymbol{t + 1}}$ & $\mathbf{C}_{\boldsymbol{t}+\mathbf{1}}$ \\
\hline 2015 & 0,81104 & $2013,2014,2015$ & $-49,12$ & 0,025 & 0,764 & 0,085 & 0,761 & 0,12 \\
\hline 2016 & 0,71489 & $2013,2014,2015$ & $-98,82$ & 0,051 & 0,691 & 0,065 & 1,092 & 0,15 \\
\hline 2017 & 0,51761 & $2014,2015,2016$ & 275,64 & $-0,132$ & 0,613 & $-0,086$ & 1,594 & 0,25 \\
\hline 2018 & 0,80147 & $2015,2016,2017$ & $-77,34$ & 0,041 & 0,715 & 0,104 & 2,592 & 0,35 \\
\hline 2019 & 0,58001 & $2016,2017,2018$ & $-52,12$ & 0,023 & 0,625 & $-0,036$ & 3,582 & 0,49 \\
\hline 2020 & 0,56003 & 2018,2019 & 221,46 & $-0,112$ & 0,546 & $-0,132$ & 4,582 & 0,65 \\
\hline
\end{tabular}

Source: based on calculations [8]

So, analyzing the data in the table we can say that the machine-building enterprise PAT AK «Bohdan Motors» there is a tendency to crisis phenomena. Therefore, it is necessary to use tools to balance ways of financing resources to minimize risks and ensure the expansion of sales, it is also necessary to take into account the indicators of receivables and payables, indicating negative trends, as we do not expect data to improve. Among the main causes of the crisis at this company should be noted: the entry into the market of cheaper and higher quality imported products, as a result of reduced production PAT AK «Bohdan Motors»; shortage of capital and technology; focus on foreign markets; shortage of capital and technology; limited access to credit and high interest rates; information crisis; lack of qualified personnel; lack of own and borrowed funds.

Along with the causes of the crisis, it should be noted that the analyzed company is ineffective crisis management. Among the main problems of crisis management at the enterprise should be noted: the creation of a strategic plan for enterprise development, but without the formed strategy of crisis management, which led to the deterioration of the situation at the enterprise; lack of marketing research; lack of comprehensive market research in Ukraine and the world; unsatisfactory pricing system affected the effectiveness of crisis management PAT AK «Bohdan Motors»; lack of organization of product promotion, not high quality of goods, unattractive appearance, inconvenient sales conditions; lack of a specialized unit for crisis management; lack of effective tools for crisis management; involvement of unqualified personnel in the process of crisis management; lack of information data for crisis management.

In our opinion, taking into account the identified causes of crisis phenomena and the problem of crisis management, it is advisable to suggest ways to combat crisis phenomena in the enterprise and use anti-crisis management mechanisms. First of all, it is advisable to support investment in electoral processes, motivation of shareholders. Maintaining solvency by controlling customer accounts and reviewing financial management will help to effectively bring the company out of the crisis. It is also necessary to accumulate reserve funds for the necessary growth of current and non-current assets with which you can ensure a high increase in production, justification of feasibility of investment projects, optimization of production costs. Also in the implementation of crisis management it is advisable to reduce costs; closure of divisions of the enterprise; dismissal of staff; reduction of production and sales; sufficient level of informatization; application of effective management tools. 


\section{Conclusions}

Thus, among the main tools to be used in the implementation of crisis management in the enterprise PAT AK «Bohdan Motors», are: insurance of financial risks to cover the deficit of equity, taking measures to achieve receivables, reducing financial transactions in the most risky areas of activity, the introduction of anti-crisis rehabilitation and restructuring. These measures will increase the number of suppliers, increase production. Therefore, it is necessary to stabilize the performance of the enterprise by reducing the share of waste in the production process, increase the efficiency of use of fixed assets, as well as reduce credit liabilities, which will reduce the financial cycle. Limiting the growth of short-term liabilities compared to long-term ones will help increase the efficiency of current production activities, will help maintain solvency by controlling customer settlements. In addition, taking into account the causes of crisis phenomena, problems of crisis management and the use of ways to combat the crisis in the studied enterprise will increase the efficiency of management, improve performance.

\section{References}

1. Banera, N.P. (2016). Antykryzove upravlinnia yak odyn iz shliakhiv vykhodu iz finansovoi kryzy [Anti-crisis management as one of the ways out of the financial crisis]. Hlobalni ta natsionalni problemy ekonomiky - Global and national economic problems, 10, 266-269. Retrieved from http://global-national.in.ua/issue-10-2016/18-vipusk-10kviten-2016-r/1885-banera-n-p-antikrizove-upravlinnya-yak-odin-iz-shlyakhiv-vikhodu-iz-finansovoji-krizi [in Ukrainian].

2. Vynokurova, O.I. (2014). Rol biznes-planuvannia v antykryzovomu upravlinni pidpryiemstv [The role of business planning in anti-crisis management of enterprises]. Naukovyi visnyk Natsionalnoi akademii statystyky, obliku ta audytu - Scientific Bulletin of the National Academy of Statistics, Accounting and Auditing, 3 (42), 54-61 [in Ukrainian].

3. Voitsekhovskaia, A.N. (2005). Antykryzysnoe upravlenye fynansamy predpryiatyia [Anti-crisis management of enterprise finances]. Visnyk Kyivskoho instytutu biznesu ta tekhnolohii - Bulletin of the Kyiv Institute of Business and Technology, 1, 70-72 [in Ukrainian].

4. Huk, O. V. (2015). Antykryzove upravlinnia yak sposib zapobihannia bankrutstvu pidpryiemstva [Anti-crisis management as a way to prevent bankruptcy of the enterprise]. Ekonomika: realii chasu. Naukovyi zhurnal Economics: the realities of time. Scientific journal, 6 (22), 193-198 [in Ukrainian].

5. Davydenko, V. V. (2016). Vykorystannia preventyvnoho antykryzovoho upravlinnia v diialnosti pidpryiemstv [The use of preventive anti-crisis management in the activities of enterprises]. Ekonomichnyi visnyk Natsionalnoho tekhnichnoho universytetu Ukrainy «Kyivskyi politekhnichnyi instytut» - Economic Bulletin of the National Technical University of Ukraine «Kyiv Polytechnic Institute», 13, 279-283 [in Ukrainian].

6. Dmytrenko, A.I. (2009). Stratehii antykryzovoi diialnosti promyslovykh pidpryiemstv [Strategies of anti-crisis activity of industrial enterprises]. Visnyk Kryvorizkoho ekonomichnoho instytutu KNEU - Visnyk of Kryvyi Rih Economic Institute of KNEU, 4 (20), $49-53$ [in Ukrainian].

7. Zanora, V. O. (2011). Stan pidpryiemstv mashynobudivnoi haluzi Ukrainy [The state of enterprises of the machinebuilding industry of Ukraine]. Vseukrainskyi naukovo-vyrobnychyi zhurnal. Stalyi rozvytok ekonomiky. Ekonomika ta upravlinnia natsionalnym hospodarstvom - All-Ukrainian scientific and production journal. Sustainable economic development. Economics and management of the national economy, 3, 37- 41 [in Ukrainian].

8. Garkusha, N.M., Tsukanova, O.V., \& Goroshanska, O.O. (2012). Modeli i metody pryiniattia rishen v analizi ta audyti: navch. posib. [Models and methods of decision making in analysis and audit: textbook]. Kyiv: Znannia [in Ukrainian].

9. Ofitsiinyi sait PAT AK «Bohdan Motors» [Official site of PJSC JSC «Bogdan Motors»] busplant.bogdan.ua. Retrieved from http://busplant.bogdan.ua/ [in Ukrainian].

10. Pohrishchuk, H.B. (2016). Identyfikatsiia finansovoi kryzy na pidpryiemstvi [Identification of the financial crisis at the enterprise]. Ekonomika ta suspilstvo - Economy and Society, 3, 463-469. Retrieved from http://dspace.wunu.edu.ua/handle/316497/5629 [in Ukrainian].

11. Rekova, N.Iu., \& Yasynska, N.A. (2015). Antykryzovi rezervy formuvannia finansovoho potentsialu instytutsiinoi infrastruktury [Anti-crisis reserves of formation of financial potential of institutional infrastructure]. Molodyi vchenyi: naukovyi zhurnal - Young scientist: scientific journal, 12 (28), 82-89 [in Ukrainian].

12. Skibitskyi, O.M. (2009). Antykryzovyi menedzhment [Crisis management]. Kyiv: Center for Educational Literature [in Ukrainian].

13. Cherep, A.V., \& Korzhenevska, V.M. (2017). Vykorystannia ekonomichnykh instrumentiv v systemi antykryzovoho upravlinnia pidpryiemstvom [The use of economic instruments within the system of enterprise crisis management]. Aktualni problemy ekonomiky - Actual problems of economy, 1 (187), 177-187 [in Ukrainian].

14. Yarenko, A. V. (2015). Systematyzatsiia kilkisnykh metodiv prohnozuvannia koniektury rynku v marketynhovykh doslidzhenniam [Systematization of quantitative methods of forecasting market conditions in marketing research]. Visnyk KNU TD. Seriia «Ekonomichni nauky» - Bulletin of KNU TD. Economic Sciences Series, 3 (87), 11-18 [in Ukrainian]. 